\title{
In vitro regeneration of Anethum graveolens, antioxidative enzymes during organogenesis and RAPD analysis for clonal fidelity
}

\author{
S. JANA and G.S. SHEKHAWAT*
}

Department of Bioscience and Biotechnology, Banasthali University, Banasthali-304022, Rajasthan, India

\begin{abstract}
An efficient in vitro regeneration protocol was developed for medicinally important aromatic plant Anethum graveolens. Nodal segments were cultured onto Murashige and Skoog (MS) basal medium supplemented with different auxins and cytokinins singly as well as in combinations. The optimum callus induction $(93.33 \%)$ was obtained on medium fortified with $2.2 \mu \mathrm{M} \mathrm{N} \mathrm{N}^{6}$-benzyladenine (BA) and $0.21 \mu \mathrm{M} \alpha$-naphthaleneacetic acid. The best shoot regeneration $(85.7 \%)$ with 12.86 shoots per explant was achieved in two weeks when callus was subcultured on MS medium amended with $2.2 \mu \mathrm{M}$ BA and $1.85 \mu \mathrm{M}$ kinetin. The average length of regenerated shoots varied from 3.15 to $4.8 \mathrm{~cm}$. The rooting of regenerated shoots was nearly $100 \%$ on $1 / 4$ MS augmented with $4.9 \mu \mathrm{M}$ indolebutyric acid with a maximum root length of $5.1 \mathrm{~cm}$. Plantlets were successfully acclimatized with $60 \%$ survival rate. During organogenesis, catalase and ascorbate peroxidase activity increased while superoxid dismutase activity decreased. Clonal fidelity of in vitro raised plants has been checked by random amplified polymorphic DNA using 10 selected decamer primers. It has been found that regenerated plants are true to type plants.
\end{abstract}

Additional key words: ascorbate peroxidase, auxins, callus, catalase, cytokinins, micropropagation, PCR, RAPD, superoxide dismutase.

\section{Introduction}

Anethum graveolens Dill is an aromatic medicinal herb and a spice belonging to family Apiaceae (Jana and Shekhawat 2010a). One of the serious problems in Apiaceae is low seed set which is due to presence of male flowers, underdeveloped flowers and lack of proper pollination and fertilization (Sehgal 1978). Tissue culture offers the opportunity to develop new germplasm and it is better adapted to the changing demands (Shekhawat et al. 2009, 2010, Jana and Shekhawat 2010c).

The production of reactive oxygen species (ROS) has been associated with plant recalcitrance during

\section{Materials and methods}

Seeds of Anethum graveolens Dill were procured from Jawaharlal Nehru Krishi Vishwa Vidyalaya, Jabalpur, in vitro culture (Benson 2000). The role of antioxidant enzymes during organogenesis and somatic embryogenesis in some species have been studied in recent years (Mathur et al 2002a,b, 2008, Dutta Gupta and Datta 2003, Meratan et al. 2009, Misra et al. 2010, Sharifi and Ebrahimzadeh 2010). There are few reports on micropropagation of $A$. graveolens through axillary shoots (Sharma et al. 2004), indirect regeneration through leaf explants (Jana and Shekhawat 2010b), but to the best of our knowledge, it is the first report on Anethum graveolens regeneration from nodal explants and biochemical parameters studied in vitro.

India. Plants were raised from seeds in Botanical garden of Banasthali University. Young and tender nodes of

Received 16 July 2010, accepted 7 February 2011.

Abbreviations: APX - scorbate peroxidase; BA - $\mathrm{N}^{6}$-benzyladenine; CAT - catalase; CTAB - cetyltrimethylammonium bromide; 2,4-D - 2,4-dichlorophenoxyacetic acid; EtBr - ethidium bromide; IAA - indoleacetic acid; IBA - indolebutyric acid; Kin - kinetin; MS - Murashige and Skoog; NAA - $\alpha$-naphthaleneacetic acid; PCR - polymerase chain reaction; RAPD - random amplified polymorphic DNA; SOD - superoxidase dismutase.

Acknowledgements: The financial support provided by Department of Science and Technology, New Delhi for the Project "Banasthali Centre for Education and Research in Basic Science" under their CURIE Programme is gratefully acknowledged. G.S. Shekhawat also acknowledges financial support received from the Department of Science and Technology, Rajasthan, Jaipur.

* Corresponding author; fax: (+91) 1438 228365, e-mail: gyans.shekhawat@gmail.com 
approximately $1-1.5 \mathrm{~cm}$ were excised from 45-d-old plant. Nodal explants were thoroughly washed with tap water, then treated with Tween 20 solution for $10 \mathrm{~min}$, washed 2 - 3 times with sterile distilled water, treated with $0.01 \% \mathrm{HgCl}_{2}$ solution for $5 \mathrm{~min}$ and washed with sterile distilled water 4 - 5 times. Then explants were cultured on Murashige and Skoog (1962; MS) medium containing $\mathrm{N}^{6}$-benzyladenine (BA), kinetin (Kin), $\alpha$-naphthalene-acetic acid (NAA), 2,4-dichlorophenoxyacetic acid (2,4-D) and indoleacetic acid (IAA) at various concentrations for callus induction, formation of multiple shoots and root induction.

The basal media consisted of MS macro and micro salts, $3 \%$ sucrose and $0.8 \%$ agar (all chemicals are procured from Merck, Darmstadt, Germany). The $\mathrm{pH}$ of the medium was adjusted to 5.8 prior to adding agar. The medium was autoclaved at $121{ }^{\circ} \mathrm{C}$ and $1.06 \mathrm{~kg} \mathrm{~cm}^{-2}$ for $15 \mathrm{~min}$. Each treatment consisted of 15 flasks, each with three explants and the experiment was repeated thrice. All cultures were incubated in a culture room under 16-h photoperiod with irradiance of $40 \mu \mathrm{mol} \mathrm{m} \mathrm{m}^{-2} \mathrm{~s}^{-1}$ provided by cool white fluorescent lamps, $50 \pm 5 \%$ humidity and temperature of $25 \pm 2{ }^{\circ} \mathrm{C}$.

The primary cultures were transferred to fresh medium after 4 weeks of incubation. In the subsequent passages the regenerating masses were divided into pieces and subcultured onto the same medium for further multiplication The shoot regenerating clusters at the time of subculturing had at least one or two shoot buds. Elongated shoots $(>4.0 \mathrm{~cm})$ derived from actively multiplying cultures were separated and cultured on MS medium supplemented with indolebutyric acid (IBA) or IAA for rooting.

After $30 \mathrm{~d}$ rooted plantlets were removed from culture vessels, washed thoroughly with sterile distilled water to remove traces of agar and planted in glass jar with mixture of sterile soil, sand and Vermiculite (1:1:1). The potted plants were irrigated with MS basal salt solution, $1 / 4 \mathrm{MS}$ devoid of sucrose and myo-inositol every four days for three weeks. After 3 weeks, plants were kept under shade for $15 \mathrm{~d}$ and then transferred to greenhouse.

For estimation of chlorophyll content, the pigments were extracted in chilled $80 \%$ acetone in dark. After centrifugation, absorbance of supernatant was taken at 645, 663 and $665 \mathrm{~nm}$ and chlorophyll $a$ and $b$ contents were calculated according to Arnon (1949).

For estimation of total protein content and enzyme activity, tissue $(0.5 \mathrm{~g})$ was homogenized in $50 \mathrm{mM}$ phosphate buffer ( $\mathrm{pH} 7.0$ ) containing $1 \mathrm{mM}$ EDTA, $0.05 \%$ Triton $X-100,1 \mathrm{mM}$ polyvinylpyrrolidone, and $1 \mathrm{mM}$ ascorbate. After centrifugation of homogenate at $5000 \mathrm{~g}$ for $20 \mathrm{~min}$ at $4{ }^{\circ} \mathrm{C}$, the supernatant was used to

\section{Results and discussion}

Nodal explants grown on different phytohormone concentrations were expanded in size within $15 \mathrm{~d}$ of measure the activities of antioxidative enzymes. Protein estimation was carried out by method of Lowry et al. (1951). Superoxidase dismutase (SOD; E.C.1.15.1.1) activity was assayed by measuring its ability to inhibit the photochemical reduction of nitroblue tetrazolium (NBT) according to the method of Beauchamp and Fridovich (1971). Calculations were made by using a coefficient of absorbance of $100 \mathrm{mM}^{-1} \mathrm{~cm}^{-1}$. Ascorbate peroxidase activity (APX; E.C.1.11.1.7) was measured as the rate of hydrogen peroxide-dependent oxidation of ascorbic acid according to Chen and Asada (1989) using a coefficient of absorbance of $2.8 \mathrm{mM}^{-1} \mathrm{~cm}^{-1}$. Catalase (CAT; E.C.1.11.1.6) activity was measured by the method of Aebi (1974) using a coefficient of absorbance of $0.04 \mu \mathrm{M}^{-1} \mathrm{~cm}^{-1}$.

Clonal fidelity of in vitro raised plants was carried out by performing rapid amplified polymorphic DNA (RAPD). DNA was isolated using cetyltrimethylammonium bromide (CTAB) method (Doyle and Doyle 1990). Approximately $1 \mathrm{~g}$ leaves of in vitro raised plants and in vivo plants were pulverized in liquid nitrogen. After ethanol precipitation, DNA was resuspended in $0.002 \mathrm{~cm}^{3}$ of $1 \times$ TE buffer (pH 8.0). The DNA was quantified spectrophotometrically by taking the absorbance at $260 \mathrm{~nm}$. Agarose gel electrophoresis was done and DNA bands were visualized under UV radiation. RAPD assay was carried out by using 10 single random decamer primers following the method of Williams et al. (1990). The PCR reaction mixture

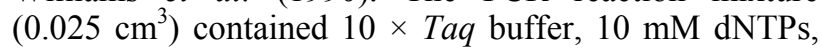
$10 \mu \mathrm{M}$ primers, 3.0 U Taq DNA polymerase (all reagents from Genei, Banglore, India), and template DNA. PCR amplification was performed in a thermal cycler (Gene Amp 9600, Perkin-Elmer, Norwalk, USA) using 44 amplification cycles, annealing temperature of $37^{\circ} \mathrm{C}$ and the last cycle was followed by 5 min extension step at $72{ }^{\circ} \mathrm{C}$. Amplified PCR products were separated on $1.5 \%$ $(\mathrm{m} / \mathrm{v})$ agarose gel in $1 \times \mathrm{TBE}(\mathrm{pH} 8.3)$ followed by ethidium bromide $(\mathrm{EtBr})$ staining. The primer sequences 5'- 3' were as follows:

$\mathrm{S} 1$ - CAAACGTCGC, S2 - GTTGCGATCC; S3 - GTCGCCGTCA; S4 - TCTGGTCAGG; S5 - TGAGCGGACA; S6 - ACCTGAACGG; S7 - TTGGCACGGG; S8 - GTGTGCCCCA; S9 - CTCTGGAGAC; S10 - GGTCTACACC. Amplification with each random primer was repeated 3 times and those primers that produced reproducible and consistent bands were selected for fidelity check.

The results were expressed as means \pm SE of three independent replicates of independent experiments. Data were subjected to analysis of variance (one way $A N O V A$ ) and Tukey's multiple range tests using SPSS version 16.0. inoculation. Callus was initiated on medium containing BA alone and combination of BA with NAA. On 

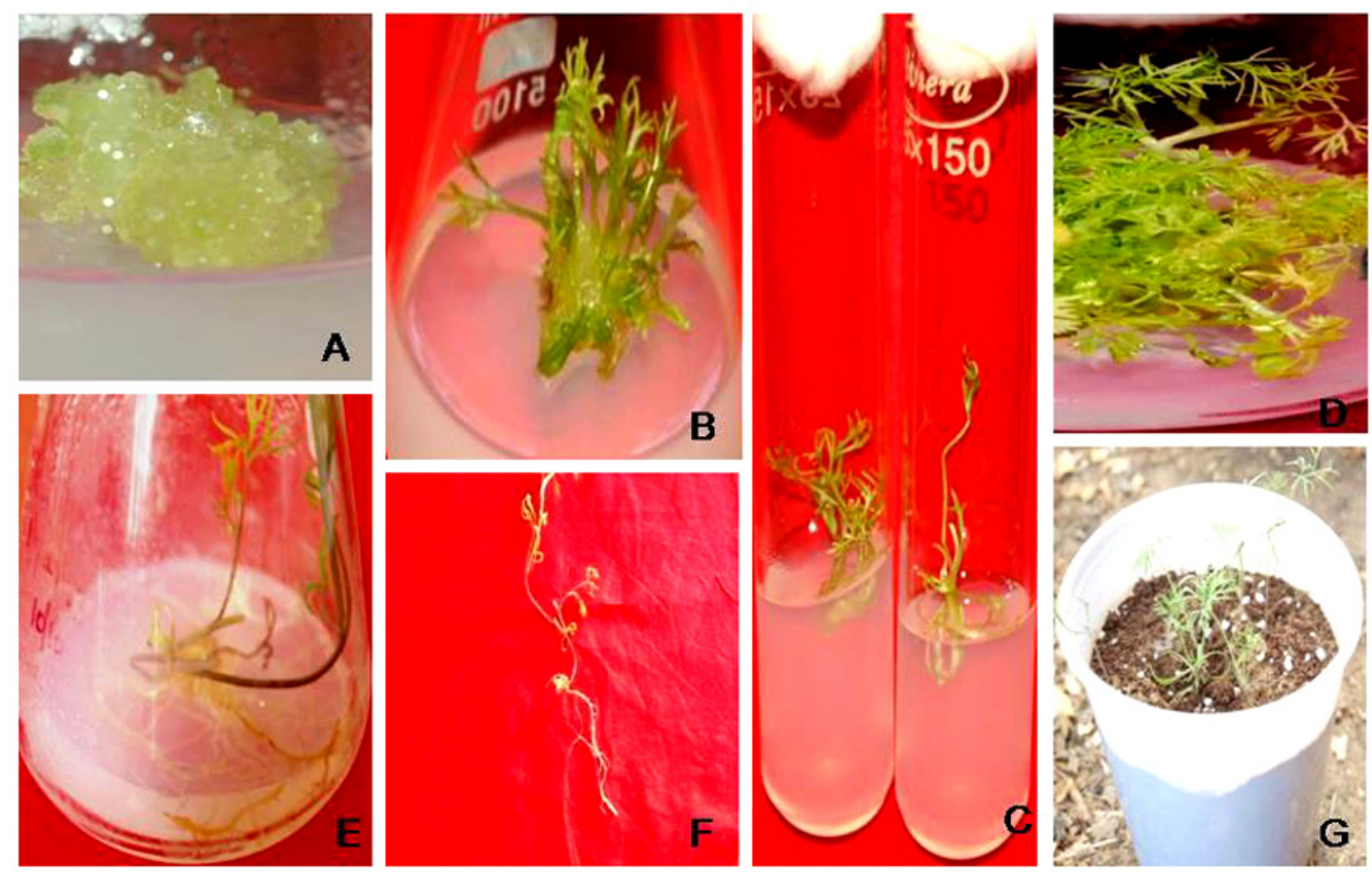

Fig. 1. In vitro regeneration of Anethum graveolens from nodal explants: $A$ - initiation of callus induction from nodal segment; $B$ - multiple shoots formation on callus surface; $C$ and $D$ - regenerated shoots; $E$ and $F$ - rooting of regenerated shoots; $G$ - hardened plantlets in sterile soil, sand and Vermiculite mixture for $20 \mathrm{~d}$.

increasing concentration of BA a gradual decrease in the percentage of explants forming callus was noted. Higher concentrations of BA $(>8.8 \mu \mathrm{M})$ inhibited callus induction. Similar reports have been observed on Pentanema indicum (Sivanesan and Jeong 2007). Callus formation on cytokinin enriched medium was found more frequent in species with strong apical dominance (Preece et al. 1991). The highest frequency of callus formation $(93.33 \%)$ was obtained with BA $(2.2 \mu \mathrm{M})$ and NAA $(0.214 \mu \mathrm{M})$ (Fig. 1A). Callogenesis was observed more at cut ends of nodes, where the callus formation might be due to the accumulation of auxins, which stimulates cell division (Marks and Simpson 1994). The maximum callus proliferation was observed when media were

Table 1. Effect of various concentrations of BA and NAA on callus induction from nodal explants of Anethum graveolens. Means $\pm \mathrm{SE}, n=15$. No response was observed at $\mathrm{BA}$ concentrations $0.4,13.3$ and $17.6 \mu \mathrm{M}$ and NAA concentration $2.14 \mu \mathrm{M}$.

\begin{tabular}{lllll}
\hline $\begin{array}{l}\text { BA } \\
{[\mu \mathrm{M}]}\end{array}$ & $\begin{array}{l}\text { NAA } \\
{[\mu \mathrm{M}]}\end{array}$ & $\begin{array}{l}\text { Callogenesis } \\
{[\%]}\end{array}$ & $\begin{array}{l}\text { Fresh mass } \\
{[\mathrm{mg}]}\end{array}$ & $\begin{array}{l}\text { Dry mass } \\
{[\mathrm{mg}]}\end{array}$ \\
\hline 2.2 & - & $80.0 \pm 0.05$ & 1730 & 62.0 \\
2.2 & 0.21 & $93.3 \pm 0.10$ & 2450 & 124.0 \\
2.2 & 0.43 & $53.3 \pm 0.15$ & 810 & 49.8 \\
2.2 & 1.07 & $33.2 \pm 0.01$ & 520 & 39.1 \\
4.4 & - & $60.2 \pm 0.12$ & 786 & 41.6 \\
8.8 & - & $26.7 \pm 0.14$ & 330 & 37.8 \\
\hline
\end{tabular}

augmented with $2.2 \mu \mathrm{M}$ BA and $0.43 \mu \mathrm{M}$ NAA. After $30 \mathrm{~d}$, fresh and dry masses of callus were recorded (Table 1).

Various concentrations of BA and Kin were tried for shoot induction and to determine the multiplication potential of shoots. On increasing concentration of Kin, green buds were observed on callus. The presence of $2.2 \mu \mathrm{M}$ BA and $1.85 \mu \mathrm{M}$ Kin was best for shoot induction after $15 \mathrm{~d}$ of subculturing with $85.7 \%$ of explants forming shoots and with 12.86 shoots per explants (Fig. 1B). The shoots were elongated on the same medium. Similarly, in Macotyloma uniflorum axillary shoots were promoted in BA alone or in

Table 2. Multiple shoot formation of Anethum graveolens from nodal explants on MS basal medium fortified with different concentrations of BA and Kin. Means \pm SE, $n=15$. Means having the same letter in each column are not significantly different at $P<0.05$ (Tukey test).

\begin{tabular}{lllrl}
\hline $\begin{array}{l}\text { BA } \\
{[\mu \mathrm{M}]}\end{array}$ & $\begin{array}{l}\text { Kin } \\
{[\mu \mathrm{M}]}\end{array}$ & $\begin{array}{l}\text { Response } \\
{[\%]}\end{array}$ & Shoot number & $\begin{array}{l}\text { Length } \\
{[\mathrm{cm}]}\end{array}$ \\
\hline 2.2 & - & $68.7 \pm 0.01^{\mathrm{a}}$ & $10.33 \pm 0.94^{\mathrm{c}}$ & $4.3 \pm 0.11^{\mathrm{e}}$ \\
4.4 & & $48.2 \pm 0.36^{\mathrm{a}}$ & $7.20 \pm 0.88^{\mathrm{c}}$ & $5.2 \pm 0.12^{\mathrm{f}}$ \\
2.2 & 0.93 & $53.7 \pm 0.15^{\mathrm{a}}$ & $8.06 \pm 0.73^{\mathrm{d}}$ & $3.5 \pm 0.22^{\mathrm{ef}}$ \\
2.2 & 1.85 & $85.7 \pm 0.78^{\mathrm{b}}$ & $12.86 \pm 0.12^{\mathrm{c}}$ & $4.8 \pm 0.22^{\mathrm{f}}$ \\
2.2 & 2.78 & $52.6 \pm 0.12^{\mathrm{b}}$ & $7.90 \pm 0.83^{\mathrm{c}}$ & $3.2 \pm 0.07^{\mathrm{f}}$ \\
2.2 & 3.70 & $25.3 \pm 0.03^{\mathrm{ab}}$ & $3.80 \pm 0.74^{\mathrm{d}}$ & $4.7 \pm 0.22^{\mathrm{e}}$ \\
4.4 & 3.70 & $12.5 \pm 0.17^{\mathrm{ab}}$ & $1.80 \pm 0.73^{\mathrm{c}}$ & $3.1 \pm 0.06^{\mathrm{ef}}$ \\
\hline
\end{tabular}


combination with other cytokinins (Varisai et al. 1999). It was also reported in Alocasia amazonica that cytokinins are responsible for optimal shoot bud proliferation and the addition of auxins could not promote shoot proliferation efficiency (Jo et al. 2008). This may be due to the interaction of auxins with cytokinins during morphogenetic events as reported by Sato and Mori (2001). Multiple shoots developed with BA $(2.2 \mu \mathrm{M})$ alone grew faster than those initiated in BA with Kin. Similar response was observed in Eclipta alba (Baskaran and Jayabalan 2005). For multiple shoot induction BA played a key role. Similar results were observed in Ormocarpum sennoides (Shanthi 2008), Adhathoda vasica (Sangeetha and Buragohi 2004) and Chlorophytum borivilianum (Kumar et al. 2010).

Table 3. Effect of various concentrations of IAA and IBA in $1 / 4$ MS medium on rooting of in vitro raised plantlets. Means $\pm \mathrm{SE}, n=15$. Means having the same letter in each column are not significantly different at $P<0.05$ (Tukey test).

\begin{tabular}{lllll}
\hline $\begin{array}{l}\text { IAA } \\
{[\mu \mathrm{M}]}\end{array}$ & $\begin{array}{l}\text { IBA } \\
{[\mu \mathrm{M}]}\end{array}$ & $\begin{array}{l}\text { Response } \\
{[\%]}\end{array}$ & Root number & $\begin{array}{l}\text { Length } \\
{[\mathrm{cm}]}\end{array}$ \\
\hline 0.57 & - & $45.61 \pm 0.15^{\mathrm{a}}$ & $2.7 \pm 0.33^{\mathrm{d}}$ & $4.1 \pm 0.14^{\mathrm{f}}$ \\
2.99 & - & $80.00 \pm 0.74^{\mathrm{b}}$ & $3.2 \pm 0.42^{\mathrm{d}}$ & $4.7 \pm 0.17^{\mathrm{f}}$ \\
5.70 & - & $86.21 \pm 0.44^{\mathrm{c}}$ & $3.9 \pm 0.79^{\mathrm{d}}$ & $4.9 \pm 0.23^{\mathrm{f}}$ \\
11.4 & - & $71.00 \pm 0.62^{\mathrm{a}}$ & $2.6 \pm 0.83^{\mathrm{e}}$ & $5.5 \pm 0.03^{\mathrm{g}}$ \\
17.1 & - & $32.32 \pm 0.05^{\mathrm{a}}$ & $2.9 \pm 1.20^{\mathrm{d}}$ & $4.9 \pm 0.23^{\mathrm{h}}$ \\
- & 0.49 & $75.05 \pm 0.26^{\mathrm{ab}}$ & $3.8 \pm 0.91^{\mathrm{e}}$ & $5.2 \pm 0.35^{\mathrm{i}}$ \\
- & 2.50 & $100.00 \pm 0.41^{\mathrm{c}}$ & $5.0 \pm 0.75^{\mathrm{e}}$ & $6.3 \pm 0.35^{\mathrm{gi}}$ \\
- & 4.90 & $100.00 \pm 0.15^{\mathrm{ac}}$ & $5.1 \pm 0.86^{\mathrm{de}}$ & $6.5 \pm 0.71^{\mathrm{gh}}$ \\
- & 9.80 & $82.11 \pm 1.28^{\mathrm{bc}}$ & $4.9 \pm 0.25^{\mathrm{e}}$ & $7.8 \pm 1.21^{\mathrm{f}}$ \\
- & 14.80 & $53.79 \pm 0.87^{\mathrm{abc}}$ & $3.6 \pm 0.43^{\mathrm{de}}$ & $5.7 \pm 0.92^{\mathrm{ghi}}$ \\
\hline
\end{tabular}

The number of shoots per explant was higher when subculturing was carried out onto the similar fresh medium at an interval of 3 weeks. The average numbers of shoot buds per explant increased up to 3 - 4 fold within 8 weeks of initial culture which could be maintained for longer periods without any loss in morphogenetic potential (Fig. 1D). The average length of regenerated shoots were found to be $3.15-4.8 \mathrm{~cm}$.

The elongated shoots were excised from shoot clumps and inoculated on $1 / 4 \mathrm{MS}$ medium containing different concentrations of IAA and IBA (Table 3 ). We have found that decreasing MS strength reduced callusing but enhanced rooting and rooting was $100 \%$ when regenerated shoots were cultivated on $1 / 4 \mathrm{MS}$ medium augmented with $4.9 \mu \mathrm{M}$ IBA. The number of roots was higher on medium with IBA $(4.9$ - 5.1) than with IAA (Fig. $1 E$ ). The length of roots per shoots varied from $4.1 \pm 0.14$ to $7.8 \pm 1.21 \mathrm{~cm}$ (Table 3 , Fig. $1 F)$. The rooted plants were suspended in $1 / 4 \mathrm{MS}$ supplemented with $24.5 \mu \mathrm{M}$ IBA with the help of sterile filter bridge in dark for $2 \mathrm{~d}$ and the developed roots turned out to be more thick and strong. The rooted plantlets were hardened and about $60 \%$ of hardened plantlets survived in botanical garden.

Activities of antioxidant enzymes and chlorophyll and total protein contents were estimated during callus induction, in organogenic callus, regenerated shoots and in vivo plants. Total chlorophyll content was found to be the higher in naturally grown plants than in in vitro cultures. Exogenous supply of carbon source may be one of the reasons for lower chlorophyll content during in vitro cultivation. Similarly, the total protein content was lowest in callus, increased significantly in plantlets, but did not reach that in naturally grown plants (Table 4). This result is in agreement with Meratan et al. (2009).

Table 4. Chlorophyll $a+b$ and total protein contents $\left[\mathrm{mg} \mathrm{g}^{-1}\right.$ (f.m.)] in callus, organogenic callus, regenerated shoots and in vivo grown plants. Means $\pm \mathrm{SE}, n=3$. Values with same letters in each column are not significantly different $P<0.05$ (Tukey test).

\begin{tabular}{lll}
\hline Samples & Chlorophyll & Proteins \\
\hline Callus & $0.27 \pm 0.09^{\mathrm{a}}$ & $136.8 \pm 0.07^{\mathrm{d}}$ \\
Organogenic callus & $0.43 \pm 0.03^{\mathrm{a}}$ & $156.4 \pm 0.98^{\mathrm{d}}$ \\
Regenerated shoots & $0.77 \pm 0.43^{\mathrm{b}}$ & $257.9 \pm 0.03^{\mathrm{d}}$ \\
In vivo plants & $1.23 \pm 0.49^{\mathrm{c}}$ & $382.8 \pm 0.02^{\mathrm{e}}$ \\
\hline
\end{tabular}

Table 5. Activities of CAT $\left[\mathrm{mol}\left(\mathrm{H}_{2} \mathrm{O}_{2}\right) \mathrm{g}^{-1}\right.$ (protein) $\left.\min ^{-1}\right]$, APX [mol(ascorbate) $\mathrm{g}^{-1}$ (protein) $\left.\mathrm{min}^{-1}\right]$ and SOD [mol(NBT) $\mathrm{g}^{-1}$ (protein) $\left.\min ^{-1}\right]$ ) observed in callus, organogenic callus, regenerated shoots and in vivo grown plants. Means $\pm \mathrm{SE} ; n=3$.

\begin{tabular}{llll}
\hline Samples & CAT & APX & SOD \\
\hline Callus & $0.88 \pm 0.09$ & $0.68 \pm 0.054$ & $0.57 \pm 0.04$ \\
Organogenic callus & $4.86 \pm 0.06$ & $0.98 \pm 0.021$ & $0.21 \pm 0.05$ \\
Regenerated shoots & $1.23 \pm 0.05$ & $0.34 \pm 0.019$ & $0.09 \pm 0.06$ \\
In vivo plants & $2.00 \pm 0.05$ & $0.86 \pm 0.067$ & $1.50 \pm 0.03$ \\
\hline
\end{tabular}

The highest CAT and APX activities were observed in organogenic callus, while SOD activity was highest in naturally grown plants (Table 5). We found that in later stages there was no callus browning or tissue damage, this may be due to low $\mathrm{H}_{2} \mathrm{O}_{2}$ accumulation due to increased activity of CAT and APX. This result is in agreement with Gladiolus hybridus where CAT and POX activity increased while SOD activity decreased during shoot organogenesis (Dutta Gupta and Datta 2003). It is also in consonance with antioxidant enzyme changes in saffron as reported by Sharifi and Ebrahimzadeh (2010). An increase in CAT activity during organogenesis is in agreement with the result of Meratan et al. (2009) in Acanthophyllum sordidum and Vatankhah et al. (2010) in Crocus sativus. Bonfill et al. (2003) reported that peroxidase activity was related to the organogenic capacity in Panax ginseng. Similar results have been seen in hybrid lily (Misra et al. 2010). Tian et al. (2003) 
demonstrated that antioxidants enzymes were involved in the process of shoot organogenesis in strawberry.

In micropropagated plants, there is always a risk of inducing genetic variability. These variations have been confirmed using various DNA marker techniques, e.g. RAPD (Padmesh et al. 2006, Zhang and Zhou 2009). This method demonstrated that regenerated plants showed genetic stability. The bands amplified through

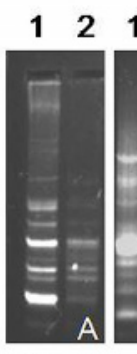

Primer S2

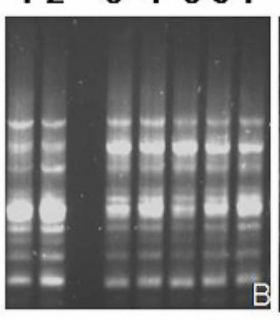

PrimerS4

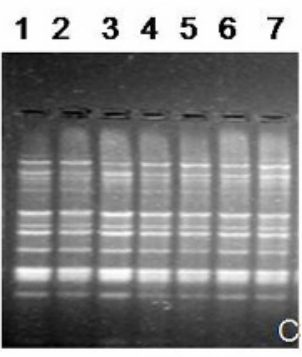

PrimerS7
Fig. 2. RAPD analysis of the regenerated plants in comparison to mother plants. $A$ - Banding profile of mother plant (1) and regenerated plant (2) with primer S2. $B$ - Banding profile of mother plant $(1,2)$ and regenerated plants $(3-7)$ with primer S4. $C$ - Banding profile of mother plant (1) and regenerated plants $(2,3)$, callus $(4,5)$ and organogenic callus $(6,7)$ with primer $\mathrm{S} 7$.

\section{References}

Aebi, H.: Catalases. - In: Bergmeyer, H.U. (ed.): Methods of Enzymatic Analysis. Pp. 673-684. Verlag Chemie, Weinheim, Academic Press, New York 1974.

Arnon, D.L.: A copper enzymes in isolated chloroplasts: polypheno oxidase in Beta vulgaris. - Plant Physiol. 24: $1-15,1949$.

Baskaran, P., Jayabalan, N.: Role of basal media, carbon sources and growth regulators in micropropagation of Eclipta alba - a valuable medicinal herb. - KMITL Sci. Technol. J. 5: 469-482, 2005.

Beauchamp, C., Fridovich, I.: Superoxide dismutase: improved assays and an assay applicable to acrylamide gels. - Anal. Biochem. 44: 276-287, 1971.

Benson, E.E.: Do free radicals have a role in plant tissue culture recalcitrance? - In vitro cell. dev. Biol. Plant 36: 163-170, 2000.

Bonfill, M., Cusido, R.M., Palazon, J., Canut, E., Pinol, T.M., Morales, C.: Relationship between peroxidase activity and organogenesis in Panax ginseng calluses. - Plant Cell Tissue Organ Cult. 73: 37-41, 2003.

Chen, G.X., Asada, K.: Ascorbate peroxidase in tea leaves: occurrence of two isozymes and the differences in their enzymatic and molecular properties. - Plant Cell Physiol. 30: $987-998,1989$.

Das, A., Kesari, V., Rangan, L.: Plant regeneration in Curcuma species and assessment of genetic stability of regenerated plants. - Biol. Plant. 54: 423-429, 2010.

Doyle, J.J., Doyle, J.L.: Isolation of plant DNA from fresh tissue. - Focus 12: 13-15, 1990.

Dutta Gupta, S., Datta, S.: Antioxidant enzyme activities during in vitro morphogenesis of gladiolus and the effect of application of antioxidants on plant regeneration. - Biol. Plant. 47: 179-183, 2003.
RAPD showed monomorphism with the mother plant and were also similar among the in vitro raised plants. The total number of bands by individual primer ranged from 6 to 10. Primer S2, S4 and S7 gave consistent bands. Mother plant, regenerated plant, callus and organogenic callus has been tested for genetic stability with Primer S7 (Fig. 2C). No variations were found and so it can be concluded that regenerated plants were true to type plants. Genetic similarity of micropropagated plants using RAPD markers have been reported in Chlorophytum borivilianum by Samantaray and Maiti (2010), in Capparis decidua by Tyagi et al. (2010) and in Curcuma species by Das et al. (2010). Xing et al. (2010) reported no somaclonal variation in regenerated eggplants raised from leaves and cotyledons and analyzed by flow cytometry, RAPD and SSR markers. This study provides the first information on genetic stability detected by RAPD markers of micropropagated $A$. graveolens plants.

To conclude, these results will encourage large-scale micropropagation of this important herb in a short span of time. Study of antioxidant enzymes during organogenesis reveals that these enzymes play a significant role during organogenesis of this plant species. RAPD analysis confirmed that the regenerated plants were genetically identical to their donor plant.
Jana, S., Shekhawat, G.S.: Anethum graveolens: An Indian traditional medicinal herb and spice. - Pharmacol. Rev. 4: 179-184, 2010a.

Jana, S., Shekhawat, G.S.: Plant growth regulators, adenine sulfate and carbohydrates regulate organogenesis and in vitro flowering of Anethum graveolens. - Acta Physiol. Plant. 33: 305-311, 2010 b.

Jana, S., Shekhawat, G.S.: Critical review on medicinally potent plant species: Gloriosa superba. - Fitoterapia 82: 293-301, 2010c.

Jo, V.A., Murthy, H.N., Hahn, E.J., Paek, K.Y.: Micropropagation of Alocasia amazonica using semisolid and liquid cultures. - In vitro cell. dev. Biol. Plant 44: 26$32,2008$.

Kumar, A., Aggarwal, D., Gupta, P., Reddy, M.S.: Factors affecting in vitro propagation and field establishment of Chlorophytum borivilianum. - Biol. Plant. 54: 601-606, 2010.

Lowry, O.H., Rosenberg, N.J., Farr, A.L., Randall, R.J.: Protein measurement with Folin phenol reagent. - J. biol. Chem. 193: 265-275, 1951.

Marks, T.R., Simpson, S.E.: Factors affecting shoot development in apically dominant Acer cultivars in vitro. J. hort. Sci. 69: 543-551, 1994.

Mathur, S., Shekhawat, G.S., Batra, A.: Micropropagation of Salvadora persica via cotyledonary nodes. - J Biotechnol. 1: 197-200, 2002a.

Mathur, S., Shekhawat, G.S., Batra, A.: An efficient in vitro method for mass propagation of Salvadora persica via apical meristem. - J. Biochem. Biotechnol. 11: 125-127, $2002 b$.

Mathur, S., Shekhawat, G.S., Batra, A.: Somatic embryogenesis and plantlet regeneration from cotyledon explants of 
Salvadora persica L. - Phytomorphology 58: 57-63, 2008.

Meratan, A.A., Ghaffari, S.M., Niknam, V.: In vitro organogenesis and antioxidant enzymes activity in Acanthophyllum sordidum. - Biol. Plant. 53: 5-10, 2009.

Misra, P., Pandey, V., Kochhar, S.: Study of antioxidant enzymes activity during organogenesis and in vitro propagation of Asiatic hybrid lily. - J. Plant Biochem. Biotechnol. 19: 119-122, 2010.

Murashige, T., Skoog, F.: A revised medium for rapid growth and bioassays with tobacco tissue cultures. - Physiol. Plant. 15: 473-497, 1962.

Padmesh, P., Reji, J.V., Jinish Dhar, M., Seeni, S.: Estimation of genetic diversity in varieties of Mucuna pruriens using RAPD. - Biol. Plant. 50: 367-372, 2006.

Preece, J.E., Hutterman, C.A., Ashby, W.C., Roth, P.L.: Microcuttings propagation of silver maple. I. Results with adult and juvenile propagules. - J. amer. Soc. hort. Sci. 116: 142-148, 1991.

Pulliah T.: Medicinal Plants in India. Vol. I. - Regency Publications, New Delhi 2002.

Samantaray, S., Maiti, S.: An assessment of genetic fidelity of micropropagated plants of Chlorophytum borivilianum using RAPD markers. - Biol. Plant. 54: 334-338, 2010.

Sangeetha, N., Buragohi, A.K.: Micropropagation of Adhathoda vasica Nees, a woody medicinal plant, by shoot tip culture. Indian J Biotechnol. 4: 396-399, 2004.

Sato, S.S., Mori, H.: Control in outgrowth of dormancy in axillary buds. - Plant Physiol. 127: 1405-1413, 2001.

Sehgal, C.B.: Differentiation of shoots buds and embryoids from inflorescence of Anethum graveolens in cultures. Phytomorphology 28: 291-297, 1978.

Shanthi, P.: In vitro propagation of Ormocarpum sennoides (Willd.) Dc. Prodr. from shoot tip explant. - Indian J. Plant Physiol. 13: 29-32, 2008.

Sharifi, G., Ebrahimzadeh, H.: Changes of antioxidant enzyme activities and isoenzyme profiles during in vitro shoot formation in saffron (Crocus sativus L.). - Acta biol. hung. 61: 73-89, 2010.

Sharma, R.K., Wakhlu, A.K., Boleria, M.: Micropropagation of Anethum graveolens L. through axillary shoots proliferation. - J. Plant Biochem. Biotechnol. 13: 157-159, 2004.
Shekhawat, G.S., Batra, A., Mathur, S.: A reliable in vitro protocol for rapid mass propagation of Azadirachta indica A. Juss. - J. Plant Biol. 29: 109-112, 2002.

Shekhawat, G.S., Mathur, S., Batra, A.: Role of phytohormones and various nitrogen inorganic and organic nutrients in induction of somatic embryogenesis in cell culture derived from leaflets of Azadirachta indica A. Juss. - Biol. Plant. 53: 707-710, 2009.

Shekhawat, G.S., Verma, K., Jana, S., Singh, K., Prasad, A.: In vitro biochemical evaluation of cadmium tolerance mechanisms in callus and seedlings of Brassica juncea. Protoplasma 239: 31-38, 2010.

Sivanesan, I., Jeong, B.R.: Micropropagation and in vitro flowering in Pentanema indicum Ling. - Plant Biotechnol. 24: 527-532, 2007.

Tian, M., Gu, Q., Zhu, M.: The involvement of hydrogen peroxide and antioxidant enzymes in the process of shoot organogenesis of strawberry callus. - Plant Sci. 165: 701707, 2003.

Tyagi, P., Khanduja, S., Kothari, S.L.: In vitro culture of Capparis decidua and assessment of clonal fidelity of the regenerated plants. - Biol. Plant. 54: 126-130, 2010.

Varisai, M.S., Jawahar, M., Thiruvengadam, M., Jeyakumar, M., Jayabalan, N.: Effect of cytokinins on the proliferation of multiple shoots in horsegram Macrotyloma uniflorum (Lan) Verdc. - J. Plant Biotechnol. 1: 79-83, 1999.

Vatankhah, E., Niknam, V., Ebrahimzadeh, H.: Activity of antioxidant enzyme during in vitro organogenesis in Crocus sativus. - Biol. Plant. 54: 509-514, 2010.

Williams, J.G.K., Kubelik, A.R., Livak, K.J., Rafalski, J.A., Tingey, S.V.: DNA polymorphisms amplified by arbitrary primers are useful as genetic markers. - Nucl. Acids Res. 18: 6531-6535, 1990.

Xing, Y., Yu, Y., Luo, X., Zhang, J.N., Zhao, B., Guo, Y.D.: High efficiency organogenesis and analysis of genetic stability of the regenerants in Solanum melongena. - Biol. Plant. 54: 231-236, 2010.

Zhang, H.Q., Zhou, Y.H.: Genetic relationships among Hystrix patula, $H$. duthiei and $H$ longearistata according to meiotic studies and genome-specific RAPD assay. - Biol. Plant. 53: 45-52, 2009. 